\title{
Globalization, migration health, and educational preparation for transnational medical encounters Peter H Koehn*
}

\author{
Address: Professor of Political Science, University of MontanaMissoula, Montana, 59812, USA \\ Email: Peter H Koehn* - peter.koehn@umontana.edu \\ * Corresponding author
}

Published: 30 January 2006

Globalization and Health 2006, 2:2 doi:10.1 186/1744-8603-2-2
Received: 10 July 2005

Accepted: 30 January 2006

This article is available from: http://www.globalizationandhealth.com/content/2/1/2

(c) 2006 Koehn; licensee BioMed Central Ltd.

This is an Open Access article distributed under the terms of the Creative Commons Attribution License (http://creativecommons.org/licenses/by/2.0), which permits unrestricted use, distribution, and reproduction in any medium, provided the original work is properly cited.

\begin{abstract}
Unprecedented migration, a core dimension of contemporary globalization, challenges population health. In a world of increasing human mobility, many health outcomes are shaped by transnational interactions among care providers and care recipients who meet in settings where nationality/ ethnic match is not an option. This review article explores the value of transnational competence (TC) education as preparation for ethnically and socially discordant clinical encounters. The relevance of TC's five core skill domains (analytic, emotional, creative, communicative, and functional) for migration health and the medical-school curriculum is elaborated. A pedagogical approach that prepares for the transnational health-care consultation is presented, with a focus on clinical-clerkship learning experiences. Educational preparation for contemporary medical encounters needs to include a comprehensive set of patient-focused interpersonal skills, be adaptable to a wide variety of service users and global practice sites, and possess utility in addressing both the quality of patient care and socio-political constraints on migration health.
\end{abstract}

\section{Introduction}

Migration, transmigration, [1] return migration, and remigration constitute defining elements of the current and future world order. More than 700 million people (including visitors on business or personal/family trips) traverse nation-state borders annually $[2,3]$ and one million per week move between the global South and the global North [4]. The enormity of contemporary transnational mobility is illustrated by the case of Australia. In the past half century, Australia's "resident population has doubled, while the movement of people across its international boundaries (that is, into and out of Australia) has increased nearly one hundredfold" [5].

In a related development, cross-border migration for settlement in a new country increased more than twice as rap- idly as the world's population grew during the last third of the Twentieth Century [6]. By 2000, about 185 million migrants resided legally or without documentation outside of their country of origin [2]. More than 55 percent of all residents of New York City, the world's most globally resettled metropolis, and 40 per cent of the residents of the state of Massachusetts are recent newcomers or children of immigrants/refugees $[7,8]$.

Twenty-first Century demographic dynamics present new health-care challenges. In many German hospitals, for instance, migrant patients and their offspring occupy a majority of the beds in maternity and pediatrics wards. Since 2000, six of every ten babies delivered in New York City had at least one foreign-born parent [7]. Increasingly, 
hospitals across the United States are challenged to provide emergency care for undocumented migrants [9].

World-wide migration and the other interconnected transborder processes that constitute the heart of globalization [10-12] "are mixing people and microorganisms on an unprecedented scale" [[13], p.196, [12]] at breakneck speed [2]. As a consequence of the historic underfunding of research focused on tropical diseases, [15] globalization means that unprepared health centers and laboratory facilities in the North confront increasing exposure to neglected pathogens and health problems that afflict the South. People on the move can either "introduce new or previously eradicated diseases to the region of destination, or contract diseases unknown to the migrants' region of origin" [[16], p.85]. Recent examples include the rapid transcontinental transmission of Severe Acute Respiratory Syndrome (SARS), the spread of the polio virus from northern Nigeria to Indonesia [17-21], and the threat of an avian influenza pandemic [22]. Frequently, moving also adversely affects the migrant's mental well-being, adding to the burden of disease $[16,11]$.

As more people in spatial transition compress the distance/time transmission of infectious and life-style-linked diseases, health protection, treatment, and promotion for migrants assume increasing consequence for individual patients, receiving societies and health-care systems, $[23,24,2]$ and for global futures [25]. Downstream from many of the sources of infectious disease and the onset of chronic illness, [11] migrants and health professionals come together in medical-treatment and health-promotion encounters. In the context of contemporary population mobility, many health outcomes are shaped by transnational interactions among care providers and care recipients who meet in settings where nationality/ethnic match is not an option. In transnational consultations, clinicians and patients often deal with a wide variety of unfamiliar health threats and behaviors $[26,27]$. Prospects for reaching individually and socially positive outcomes are complicated when incongruent perspectives regarding physical and/or mental health problems, objectives, means for resolving problems, and outcomes prevail among professionals and service users of diverse nationality $[28,29]$.

The rise of issues surrounding the movement of populations and pathogens across porous borders signals a growing concern with "migration health" [16]. Most studies of human migration and health emphasize national security concerns, surveillance, and/or policy responses involving population containment and exclusion. This review article focuses on the need to reorient a different dimension of global health governance: physician education. Education for transnational care merits special attention for at least three reasons: (1) medical professionals (physicians, mental-health-care providers, nurses, public-health specialists, and their teachers) form the backbone of the health sector throughout the world; (2) preparing physicians for cross-national medical encounters offers a change strategy that is proactive and encompasses the creation of health gain in a world characterized by continued population exchanges rather than a strategy that is exclusively or primarily reactive and preoccupied with eliminating disease; [30] and (3) medical-school education holds out the promise of contributing to the reduction of health disparities in an immediate and observable fashion.

\section{Physician education in a globalizing world}

Throughout the global North and the global South, physicians are encountering patients in spatial transition from a multitude of dissimilar nation states [7] or ethnic communities. Contemporary medical-school curriculums and continuing education have not kept pace with the challenges that accompany an era of global mobility. In addition to multiple nationalities, physicians are challenged by bicultural, multicultural, and third-culture (different from both origin and host) [31] patients. Culture-competence education, initially intended for mastery of specific domestic two-culture interactions, [32] is of limited utility in today's diverse, hybrid, and rapidly changing patientcare environment $[33,28]$. Leyla Cinibulak reports, for instance, that "while health care providers [in the Netherlands] use a static notion of culture in their approach to migrant women, the Turkish migrant women's own approach towards the traditional values and taboos of their culture of origin and their religion is pragmatic and flexible" [[34], also [35]].

The multidimensional richness of human experience generates considerable intragroup variation $[36,37]$. Thus, migrants from a common sending place rarely share the same socio-economic and political backgrounds and mobility experiences $[38,39]$. Recipes of cultural characteristics miss the complexity of perspectives and behaviors that exist within ethnic groups due to varied social origins and behavioral inclinations, exposure to different experiences, mixed and emerging identities, and uneven transborder ties and involvements [40]. As Marjorie KagawaSinger and Shaheen Kassim-Lakha illustrate:

"What information does 'Chinese' convey? This man could have been born in Hong Kong, be a college professor who speaks five languages including English, and lives six months of the year in the United States and six months in Hong Kong. This man could also be a monolingual Chinese gentleman, born in the United States, unmarried, and living alone in Chinatown in New York, with little education and very poor [[33], p.579]." 
Given the diverse, changing, and transgenerational nature of contemporary patient populations, [41] today's clinician must be skilled in identifying the special circumstances that surround and define each individual's health.

Educators increasingly appreciate that health is a global public good. The distribution of this good remains vastly unequal, however. Irrespective of ethnicity or culture, people who are poor "tend to experience more health problems in general over the course of their lives than do their more socioeconomically advantaged counterparts" [[42], p.504]. In large measure, disparities in health status reflect coping practices that are mediated by socio-economic position and ability to access and use health-care opportunities $[28,43,12]$ In the global South, the most common social and economic determinants of medical problems and suffering are poverty, undernourishment, lack of access to safe water, absent or deficient sanitation, unhygienic housing conditions, $[44,45]$ and, increasingly, a critical shortage of trained health workers - many of whom have emigrated to rich countries [46].

Individuals and families on the move frequently confront additional health risks associated with "health-compromising working and living conditions" along with inequities in health-care access and medical treatment [[47], p.126, [48,49]]. Individual health-care abilities and opportunities are not independent of forces linked to globalization - including economic, political, and military incursions that result in displacement and migration [50]. A recent African war-zone study carried out by Physicians for Human Rights concluded that the "first killer is flight" for desperately poor persons driven by conflict from a fragile existence into a hostile and personally threatening environment where health services are nonexistent or not functioning [51]. Migrants who leave behind safe social settings often are obliged to congregate in vulnerable spatial surroundings. Mobility simultaneously facilitates cumulative social-change processes (including isolation, marginalization, segregation, and discrimination) and risk-taking behaviors that are associated with increased susceptibility to and spread of noncommunicable as well as communicable disease $[47,49,52-54]]$. For this reason, HIV/AIDS researchers are devoting increased attention to the role of social disruption and migration to "hot spot" environments in fueling the epidemic $[47,12,55]$. To add insult to injury, the health problems of displaced and otherwise dislocated people tend to be officially "invisible" and are likely to be bypassed by potentially beneficial interventions [56].

"Irregular" and undocumented population movements pose special challenges of migration health. At all stages of migration (transportation, transit, and settlement), irregular migrants (including persons smuggled and traf- ficked) "are particularly exposed to contracting or transmitting diseases, to injuries or even death" [[16], pp.90-91, [57]]. The vulnerability of irregular migrants is exacerbated by poverty, powerlessness, the absence of social and legal protection, and lack of access to reliable health-care services. This situation often obliges them to seek medical attention through unofficial and unsafe means [16].

Although the reasons for disparities in health-care screening, medical procedures, morbidity, and mortality among persons who lack "voice" in biomedical institutions are multiple and complex, [58] the clinician/patient relationship constitutes an important contributing - and potentially mitigating - factor [59,60,48]. Carefully designed consultations enable public-health professionals to identify specific resources and support that will empower patients when addressing the challenges to positive health outcomes they face in the host society. Supportive actions on behalf of disadvantaged and underserved patients include facilitating access to social and health services provided by the host society; facilitating access to traditional healers and medicine as well as scarce (but, sometimes locally available) indigenous nutritional supplements; facilitating access to lay (community) health workers and intercultural mediators; assisting with the development of host-country language proficiency; promoting further education and credential (re-)certification; facilitating employment; help with moves into improved housing; [61] promoting the maintenance of children's healthy practices; [31,62] encouraging legal/ policy coalition building with host-society institutions and transnational NGOs; and acting as the patient's advocate within the medical establishment and with government agencies and community associations.

In general, however, "the possibility of physicians working to improve contextual sources of distress" has been "overlooked" in medical education [[63], p.5, [64]]. Addressing power blinders [65] as well as social and political barriers to greater equity in access to health care falls outside the scope of most medical-school curriculums [64]. Without redirection, then, advocacy on behalf of a diverse and shifting circle of patients will continue to be viewed as peripheral, optional, and/or beyond one's capacity by future generations of physicians [66].

\section{Redirecting the medical-school curriculum: Preparing for patients in transition}

In our age of globalization and dislocation, health-care initiatives and interactions need to be informed and supported by enhanced educational capacity [67]. The transnational competence (TC) framework [68] provides a valuable skill foundation for curriculum reform. The comprehensive set of practical skills that comprise the core of 
a TC education offer a promising emerging avenue for redirecting medical-school curriculums in ways that specifically and effectively address the connection between migration and health disparities. TC approaches transnational clinical encounters as micro-level interpersonal interactions that occur in a social/power context and are directly and indirectly shaped by macrolevel (global, regional, national, and local) structural factors. Advocacy is a conceptually integral skill component in TC preparation. Medical students are expected to address the social and power context, and to promote the health rights, of patients undergoing spatial, social, and identity transitions through specific recommendations that are critiqued, refined, and evaluated by faculty, preceptors, and care receivers.

TC education is based on a set of key principles, addresses the framework's five core skill domains, and utilizes a reinforcing pedagogical approach. Given that population mixing is widespread in the South as well as the North and that foreign-trained health-care professionals play a growing role in the health sector of many nations, $[69,70]$ TC education needs to be available on a world-wide basis.

\section{TC principles}

The first principle of TC education is patient-centered learning. The medical consultation is approached as a partnership, with the patient participating as teacher as well as learner and the student valuing the learning and mentoring dimensions of his/her role [58,71]. The patient's voice is treated as an indispensable source of expertise and experiential insight $[37,72]$. Rather than ignoring the perspectives of the least advantaged, [64] preparation for the TC encounter revolves around patientoriented inquiries that are designed to promote congruent perspectives among care seekers and care providers on health status and health promotion - regardless of differences in national origin, ethnicity, cultural identity(ies), and socio-economic (and political) status. Findings from clinical studies consistently show that, when treated as an interactive, partnership-based process, [73] the medical consultation directly and indirectly improves the outcome of health-care interventions [74,59,58,71]. The TC approach anticipates, therefore, that health-care outcomes will be enhanced when patients also possess transnational competence [75] and demand and inspire corresponding skills on the part of the clinicians who consult with them.

TC's second core principle holds that patient advocacy is an indispensable physician activity. A TC education aims to move learners beyond patient sensitivity into responsiveness to patient needs. Across its five skill domains, the TC framework remains focused on two interconnected objectives: improved short- and long-term health outcomes for patients in spatial transition and reduced health inequities for dislocated populations and disadvantaged communities. Both objectives lie at the core of the People's Charter for Health that emerged from the People's Health Assembly held at Savar, Bangladesh, in 2000 [76].

A third TC principle centers on the resilience of underserved patients and families. TC preparation starts from the premise that patients in spatial transition are resilient and searches for ways to reinforce and expand their capacity to tap into potentially rich reservoirs of family, community, and transnational health-care resources.

\section{TC domains}

The TC framework explicitly encompasses five discrete, but mutually reinforcing, skill domains. Transnational competence involves mastery of analytic, emotional, creative/imaginative, communicative, and functional skills. Each skill domain encompasses multiple dimensions.

\section{Transnational analytic skills}

The analytic domain of TC preparation focuses on developing the ability to gather and analyze evidence related to the patient's health rather than on stored knowledge, while recognizing that a knowledge-based approach can be useful for specific and limited purposes $[27,48]$. In particular, TC education recognizes the necessity to probe beyond ethnicity/culture. As Moustafa Bayoumi observes, "by obsessively focusing on culture, we avoid talking about history, economics and politics" [[77], p.A4]. In short, an exclusively ethnic/cultural observation "obscures the social and structural basis of the need ..." [[37], p.34]. The interweaving of ethnocultural, sociopolitical, and medical analyses is required for comprehensive assessment of each patient's health-care needs.

To avoid misinterpreting messages and explanations offered by patients in spatial transition, medical students must develop expanded receptors for discerning political and socio-economic determinants of individual health; $[78-82,62]$ that is, they must learn how to perceive health situations through what Mary Duffy refers to as the patient's "global lens" [[36], p.489]. In particular, it is important that medical practitioners elicit and explore the longitudinal dimensions of spatial transition given that established as well as recent migrants often are dealing with "unfinished endings" that preceded their arrival in the current locale [[38], p.89, [83]] and continue to shape their lives [84,85]. Physicians possessing transnational analytic skill are able to comprehend and critically appraise the internal and external forces that affect migration health $[86,87]$ by expanding the medical discourse to include linked macro-structural and micro "origins of personal suffering" [[63], p.276] - such as war, [48,88,89,84] manipulations of national and subnational economies by powerful global institutions, $[87,90-92,12]$ foreign policy, 
[86] powerlessness, [93] persecution, and the type, combination, and frequency of trauma experiences [94].

Transnational analytic skill further involves unraveling existing linkages between migrant health and post-migration constraints and stressors associated with receivingcountry reception practices and new developments in the country of origin [95-97]. For instance, a patient's capacity for self-care can be limited by ongoing "cultural and linguistic isolation, fragmentation of the family, deformation of social relationships, chronic absence of adequate support systems, poverty, prejudice, and unemployment" [[98], p.32, [59], [63,99-103]] - all rooted in migration and post-migration experiences. Furthermore, political and family events and conditions in the sending country often continue to affect the mental health and physical well-being of service users who possess transnational ties and identities [104,84].

Another critical transnational analytic skill in migration health is the ability to ascertain the role of ethnocultural and other nonstandard health-related beliefs, values, practices, and paradoxes. The "transnational healing" practices of some contemporary migrants even include return to the country of origin for medical attention and treatment $[105,106]$. TC education prepares students to assess the role of nonbiomedical considerations in the pre- and post-migration explanatory model and decisionmaking processes of specific patients and/or families [107-112]. Box 1 presents illustrative TC-preparation components in the analytic domain.

\section{Box I}

Illustrative TC-preparation components: Analytic domain

1. Develop the theoretical base for analyzing the particular socio-economic and political factors that mediate experience and influence health-care delivery for the individual patient.

a. Introduce useful concepts from waste and consumption studies $[113,114]$

i. notion of a chain, with individual decision nodes that tend to be severed from contextualized understanding of shaping and constraining upstream and downstream social forces and power relations that invoke hidden costs.

ii. process of distancing; that is, stretching the chain (geographically, culturally, and mentally). Mental distance includes gulfs of information, awareness, and responsibility.

iii. possible applications when analyzing transnational health care
1. recognize the need to move upstream and downstream along the health chain in the effort to uncover specific case-relevant contextual social forces and power relations. Raise consciousness that individual medical care alone cannot be sufficient to sustain practices that will maximize the patient's health potential.

2. recognize that moving upstream and downstream intergenerationally is likely to yield divergent as well as overlapping insights.

b. Connect concepts (including class, identity, power, and distancing) to the ability to discern and analyze critically [64] the distant political/economic/social/environmental contributors to proximate health "variability, vulnerability, and strength" [[33], p.579, [115]]; specifically, the interaction of dislocation and transit experiences (including types, extent, and duration of persecution and trauma) with:

i. different migration decisions and forms of migration forced, planned and long-term, planned and short-term [2]

ii. structural inequities embedded in conditioning institutions

iii. linked macro and micro, local and global forces

c. Connect concepts (including class, identity, power, and distancing) to the ability to discern post-migration conditions affecting the patient's current health-related beliefs and practices and physical and mental health in the receiving society. Potentially influential post-migration conditions include:

i. social/political experiences and stressors

ii. simultaneous and potentially conflicting home- and host-country expectations and medical treatments

iii. differential access to health-care system and treatment opportunities

iv. altered nutrition practices

v. immigration status

vi. occupational and employment transitions

vii. (il)literacy and education

viii. housing \& transportation situation

ix. (lack of) support networks 
$\mathrm{x}$. extent, and positive and negative effects, of adaptation [31]

d. Connect concepts to skill in discerning life-style and health consequences of the patient's changing class profile - often characterized by radical downward mobility in the case of involuntary (politically dislocated) migrants and upward mobility for voluntary (economic) migrants (accompanied by exposure to new risks and the adoption of detrimental health behaviors)

2. Develop ability to discern the patient's ethnocultural identification(s) and personal (including nonbiomedical) beliefs and practices regarding causes, treatment, and prevention of illness.

3. Develop understanding of how the degree of one's cultural, ethnic, and socio-economic match with the patient influences the therapeutic relationship [115]. Learn to avoid the "cultural blind spot syndrome" where the clinician assumes no distinctive health-care beliefs/practices exist because the patient looks and behaves much the same way as $\mathrm{s} /$ he does $[116,117,28]$.

4. Develop ability to utilize analytic techniques transnationally

a. by locating and learning from helpful proximate and reliable current sources

i. ethnic community

ii. ethnic health specialists

iii. intercultural mediators

iv. other care providers (nurses, social workers)

v. internet \& telemedicine

vi. published research findings

b. by using general information about population-specific disease incidence/prevalence/outcomes, new and emerging diseases, and antimicrobile resistance [2] and the patient's places of origin and transit, ethnicity, cultural and spiritual practices, previous sources of health care, migration/trauma experiences, economic situation, degree of societal incorporation, and support systems as a starting point for physical/mental-health inquiry, confirmation/ disconfirmation, and recommended therapies/ referrals c. by accessing and assessing information regarding the pharmacological properties of the care recipient's ethnocultural preparations (ethnopharmacology) [48]

d. by eliciting comprehensive patient narratives and explanatory frameworks that move beyond the prevalent "brief and perfunctory social history" [118]

\section{Transnational emotional skills}

Transnational emotional competence includes the ability to express interest in different cultural patterns - language, family life, dietary practices, [119] customs, etc [120] - and the ability to gain and maintain genuine respect for a multiplicity of values, beliefs, traditions, experiences, challenges, preferred communication styles, and feelings of satisfaction and emotional distress stemming from social circumstances [63,34]. Among medical students preparing for encounters with patients of multiple nationalities and diverse identities, the emotional skill domain is developed through interest in interacting with ethnically, culturally, and economically diverse patients. The application of transnational emotional skills requires a "willingness to try" to decipher the patient's thoughts and perspectives [[32], p.1058, [121]] - including his/her beliefs regarding the mediating effect of "luck, chance, randomness and personal destiny" on healthy lifestyles [[122], p.679] - and to respond empathically with an appropriate emotion of one's own [123].

In the migrant-health interface, it is particularly important that care providers learn to respect rather than dismiss lay expertise $[72,37]$ as well as nonbiomedical practices that affect acceptance of and compliance with treatment protocols and, therefore, influence outcomes [124-127,112]. Emotionally skillful participants also appreciate that every clinical encounter is a multidimensional interaction among the cultures of the patient, the physician, the support professional(s), and the health-care contexts/systems that surround them $[128,107,48,62]$.

The emotional-competence domain of a TC education further emphasizes appreciation for the ability of people in spatial transition to regain emotional strength and functional capacity following adversity [129]. Many "refugee patients and their families bring to health consultation stories of incredible human resilience in the most extreme circumstances" [[130], p.27, [110]]. Studies show that a sense of personal, family, and/or group efficacy constitutes a powerful determinant of the adoption and maintenance of health-promoting actions and is associated with a host of health-enhancement and illness-prevention outcomes [131-133,58]. Under the vulnerable and stressful environmental conditions that migrants face as the result of formidable language and cultural constraints, discrimination, the threat of long-term unem- 
ployment, and/or lack of social support, clinician appreciation for patient/family health-care assets, capabilities, and responsibilities reinforces individual and collective perceptions of transnational efficacy and strengthens confidence, perseverance, and power to sustain new and demanding psychological and physiological healthenhancing behaviors [132]. Capable self/family illness management is particularly valuable in treating many chronic diseases [134]. Among medical students, emotional competence also involves self-monitoring and reflection; that is, life-long openness to critical selfappraisal, to learning in place of stereotyping, [135] and to promoting emotional growth [136]. Box 2 presents illustrative TC-preparation components in the emotionalskill domain.

\section{Box 2}

Illustrative TC-preparation components: Emotional domain

1. Develop abilities to realize health-care insights through transnational empathy, to be effective at deciphering the patient's perspective, to see and take seriously problems as the ethnoculturally discordant patient experiences them, $[137,138]$ and to deliver an appropriate and reassuring emotional response.

2. Develop ability to reinforce/restore efficacy among ethnically and socio-economically diverse patients

a. by demonstrating appreciation for emotional resources (resilience) and achievements in surviving and overcoming dislocation and migration challenges and/or disparities in treatment $[115,139]$

b. by validating and protecting family-care and self-care practices that facilitate adaptation and well-being [140]

c. by identifying what patients and their support network can do for themselves with some initial outside help [141]

d. by conveying an optimistic outlook on prospects that the patient's health-care needs can be met [142,143]

3. Develop ability to show respect for (acknowledge and validate) the patient's ethnocultural and other nonbiomedical health beliefs and practices - to treat them as distinctive rather than inferior or deviant.

4. Develop ability to motivate health improvements through transnational sociophysiologic feedback [137]. This ability is important because many patients look for help in dealing with the emotional aspects of chronic or other illness and are shocked when clinicians approach their case only in terms of technical efficiency [144].

\section{Transnational creativelimaginative skills}

The freeing up of imaginative capacities is a powerful force for positive health outcomes in the transnational medical encounter [145]. A key creative skill for medical students preparing for migrant-health care is the ability to initiate fruitful new connections among distant and proximate parts of the patient's experience [146]. Skillful transnational clinicians are "creative synthesizers" [[147], p.17, [148]] who value collaboration with, and are able to inspire, participants of diverse identities (patients, family members, and transcultural mediators) in the co-design and nurturing of innovative and contextually appropriate health-action plans [149].

A substantial proportion of all health care is provided "outside the perimeter of the formal health care system" [[150], p.251]. In the migrant-health arena, innovative approaches to managing demands for medical treatment and wellness promotion include complementary integrations of biomedical and ethnocultural explanatory frameworks and health-related practices $[107,124,109,151$ $153,108,96]$ and incorporate multilevel linkages of individual, socio-political, and ecological considerations $[154,155]$. In the interest of preparing creative medical practitioners, TC education emphasizes flexibility and adaptability when confronted with unique and unfamiliar situations [37].

Imagination "makes empathy possible" by lending "credence to alternative realities" [[146], p.3]. Medical practitioners must be prepared to relate physical and emotional experiences and perceptions that shaped the decision to leave the country of origin, as well as those that arise during migration and resettlement processes, both to approaches that effectively address the patient's current health-promotion needs [152,155] and to promising social changes and policy alternatives [63]. Box 3 presents illustrative TC-preparation components in the creative/ innovative domain.

\section{Box 3}

Illustrative TC-preparation components: Creative domain

1. Ability to account for the patient's current place-specific environment (housing, social dis/organization, transportation, employment, etc.) in the tailored health-action plan.

2. Ability to forge synergetic and congruent linkages between what the patient believes and what the clinician believes [28].

3. Ability to co-create a health plan based on shared transnational synthesis - a complementary combination of biomedical and personal (ethnocultural/mixed-cultural) 
beliefs/practices that is neither clinically, culturally, nor economically contraindicated $[115,156,81]$.

4. Ability to activate and incorporate the patient's own ideas, suggestions, resources, and ingenuity into the mutually agreed-upon health plan.

5. Ability to account for the ethnoculturally discordant patient's unique life context (physical and emotional experiences and institutional forces) in the tailored health-action plan.

6. Ability to construct a tailored health-promotion action plan that includes societal reinforcement for linked phys$\mathrm{ical} /$ mental-health interventions [115].

\section{Transnational communicative facility}

Effective provider-patient communication is widely perceived as "a core competency in the health care profession" [[59], p.27, [58,48]]. While personal linguistic fluency in the patient's first language is an immense behavioral asset, [157-161,48] achieving it is impractical in transnational health-care situations involving multiple first languages [32]. In New York City, for instance, patients might speak one of 150 different languages [162] Thus, TC education emphasizes skill in using an interpreter, the importance of employing trained medical interpreters, [163-166,153,158,160,111,157,48] and host-language preparation and communication training for patients [134].

Transnationally skillful actors also develop proficiency in nonverbal-communicative behavior. In medical encounters, "nonverbal communication skills ... are as important as verbal skills, if not more so" [[167], p.2445]. In transnational medical interactions, interview pace, speechsimplification strategies, and the use of "continuers" ensure that participants are not rushed, prematurely interrupted, ignored, or incompletely understood [168170,164]. In addition, communication-recovery skills, such as humor, apology, and admission that one does not know everything, "reinforce confidence as well as competence because, when it is known that there is something to fall back on, one is less likely to avoid interactions that may prove difficult" [[96], p.245, [135]].

The capacity to engage in meaningful dialogue and to facilitate mutual self-disclosure via questioning is particularly important in transnational health-care situations characterized by vast social distance [168]. Similarly, a prerequisite for negotiating appropriate treatment plans and commitment to agreements is that participants especially migrant patients - are comfortable expressing serious doubts and constructive challenges $[168,63,58]$.
Box 4 presents illustrative TC-preparation components in the communicative-skill domain.

\section{Box 4}

Illustrative TC-preparation components: Communicative domain 1. Ability to select the most helpful interpreter for each patient's specific cultural, linguistic, and social context

2. Ability to use best practices associated with the participation of interpreters in clinical consultations [156]

3. Proficiency in patient-appropriate non-verbal communication

4. Proficiency in active listening and taking the patient seriously [138]

5. Ability to use speech-simplification strategies

6. Communication-recovery skills

7. Ability to facilitate mutual self-disclosure [33]

8. Ability to convey health-care options and recommendations across language and cultural divides

\section{Ability to elicit patient's questions and concerns}

10. Ability to elicit patient's doubts and disagreements

\section{Transnational functional adroitness}

Functional competence involves the interpersonal as well as technical ability to accomplish tasks and achieve objectives. In transnational medical encounters, the functional skills of both patients and clinicians affect illness management and wellness promotion [171,172]. In migranthealth-care consultations, effective functional interventions take into account both the individual's condition and the social context affecting health behavior [155].

Skill in establishing positive interpersonal relations is particularly valuable for the functional domain of migranthealth care. Keys to success in building fruitful transnational relationships include demonstrating genuine and sustained personal as well as professional interest in the care recipient as an individual, commitment to the patient's cognitive and instrumental needs, [137] and support for his/her social inclusion [36]. TC preparation emphasizes that, in the case of migrants who lack voice in the socio-political context they find themselves in, concern for patient well-being can be demonstrated by actions that address factors responsible for personal suffering [63]. Valuable relationship-building TC-provider interventions include helping with transportation to medical appointments, facilitating access to traditional heal- 
ers, medicine, and nutrition, promoting ties to community support networks, identifying and enhancing the development of "new roles that provide a sense of meaning and structure to daily life," [[173], p.294] and assisting with host-country language training, further education and credential (re-)certification, employment, and the maintenance of (children's) healthy practices.

The functional dimension of transnational competence also is promoted by establishing clinician/patient partnerships, or "therapeutic alliances." [135] In the transnational therapeutic alliance, "the process of negotiation between practitioner and patient involves developing courses of action that are consistent with the patient's values and goals and that also satisfy the physician's values and goals ..." [[168], p.13, [33]]. For many migrants, transculturally sustainable agreements must include involvement by (extended) family members and/or migrantcommunity support networks [111,150].

In the interest of equitable health opportunities for migrant patients, transnational functional adroitness necessitates advocacy competence; that is, recommendations/actions that will generate upstream and downstream changes in domestic and international economic, social, institutional, and policy conditions that produce the systemic disparities that constrain individual health and preclude the realization of health gains $[23,174$ $177,92,48,76,94]$. It is likely to be particularly rewarding for functional skill development to focus students' advocacy attention on local "hot spots" where migrants tend to congregate. In this part of functional TC preparation, medical students can be guided to develop specific interventions that address context- and site-specific conditions that are conducive to elevated risk-taking behavior [47]. Box 5 presents illustrative TC-preparation components in the functional domain.

\section{Box 5}

Illustrative TC-preparation components: Functional domain

1. Ability to establish and maintain meaningful transnational inter-personal relations [178].

2. Ability to relate to ethnoculturally and socio-economically discordant patients in a way that builds mutual trust

a. by showing that one genuinely is interested in, cares about, and is committed to helping with the patient's current situation and quality of life (beyond physical health) $[179,138]$

b. actions are regarded as appropriate and useful

c. conflicts are resolved to mutual satisfaction
3. Ability to apply relevant insights from the other four TC domains.

4. Ability to integrate evidence-based insights regarding the influence of ethnocultural practices and disease predispositions, class, access, migration, and trauma into patient-specific health-status hypotheses and effective health-care responses.

5. Ability to engage the patient (and/or his/her family) in making joint health/illness assessments and in developing/modifying health-promotion plans [81,180]. At times, this process requires the ability to overcome structural constraints that limit the amount of time available for consultations with patients [181].

6. Advocacy and referral skills I. Ability to build and activate host-society and migrant-community resources that are likely to enhance the patient's health situation by mitigating the site-specific environmental constraints they confront.

7. Advocacy and referral skills II. Ability to build and activate societal resources that are likely to enhance the patient's health situation by mitigating the socio-economic inequities, power differentials, exclusion policies, and other institutionalized constraints they confront.

\section{TC pedagogical approaches}

Along with introductions to challenging new material and helpful insights regarding contemporary medical practice, it is critical that future physicians be "taught in a way that works better" [182]. For maximum effect, the core elements of a TC education need to be longitudinally woven into required pre-clinical and clinical education through instructional approaches that encompass lectures, smallgroup discussions that include reference to the consequences of patient stereotyping, analysis of written and videotaped case studies, constant reference to clinical applications, interaction with community leaders, training in interviewing skills, as well as experiential approaches such as role plays, [27] encounters with simulated patients, overseas immersion, $[8,36]$ involvement in community service-learning projects, and carefully designed clinical clerkships. The didactic components of the longitudinal and integrated TC approach would establish the need for adaptable skills in the contemporary context of globalization and health, would build a comprehensive foundation of five skill domains, would highlight the special value of experiential learning and reflective practice when attending to migrants, and would emphasize the centrality of collaborative efforts to promote social justice in health care through multi-dimensionally sensitive and individual-patient responsive transnational medical encounters. Resources from the 
humanities (e.g., art, literature, autobiographical accounts of migrant-patient experiences) can be especially useful in the initial effort to awaken the student's imagination [146] and to convey TC concepts that are inherently important in caring for migrant patients [183]. To facilitate stakeholder buy-in, the instructional and experiential dimensions of TC medical education also require attention to faculty-selection criteria, resources for faculty development in skill-deficit domains and in unfamiliar pedagogical approaches, and institutional as well as external support for materials development, contributions by specialists, assessment exercises, and logistical arrangements. Medical schools and teaching hospitals also will need to reinforce or establish linkages with often fragmented migrant-community associations and with community-health advocates.

In contrast to educational methods that center on mastery of ethnic patterns of disease or lists of cultural characteristics, the predominantly inductive TC approach focuses on the patient as the starting point for discovery and avoiding mistakes $[27,184]$. When health-care providers work with diverse service seekers, skill development occurs through "bottom-up" information and evidence gathering that places primary emphasis on contextual insights derived from proximate and current sources - the patient himself/ herself and family, friends, and/or community members $[185,48]$. In light of the existence of national subcultures and the presence of intracultural (and changing) variations that occur due to "age, gender, income, education, acculturation, individual differences, and multiple other factors," general epidemiological evidence about the patient's country and its endemic diseases, ethnic group, or religious affiliation needs to be "regarded as having some bearing but requires further validation to be considered immediately useful" [[185], p.251-252, $[186,96,27,33]]$. As Melanie Tervalon and Jann MurrayGarcia point out, "only the patient is uniquely qualified to help the physician understand the intersection of race, ethnicity, religion, class, and so on in forming his (the patient's) identity and to clarify the relevance and impact of this intersection on the present illness or wellness experience"; that is, "how little or how much culture has to do with that particular clinical encounter" [[135], p.121].

For TC preparation, therefore, skill development is expected to be especially robust during the student's clinical-clerkship experiences. In a TC-informed medical education, exposure to transnational medical encounters would constitute an integral part of all clinical clerkships. Clerkships that involve migrant patients present students with a variety of stimulating medical challenges framed by diverse cultural perspectives and social backgrounds [65] and, simultaneously, provide problem-solving opportunities for students to articulate helpful recommendations and rewarding interventions. When designing each TC clerkship experience, faculty would arrange for students to work closely with patients and family members from distinct and diverse cultural, ethnic, subcultural, generational, and socio-economic backgrounds. Gerrish, Husband, and Mackenzie warn that "a de facto emphasis on cultural competence, with a resultant neglect of intercultural competence, must be resisted" [37,134,135]]. Thus, TC clinical placements and preceptor-supervised encounters with patients [121] would avoid focusing on a single local population. Clinical assignments also should proceed to levels of increasing complexity and be linked to reflective seminars that involve sharing and group discussion of case-specific and transnational issue-related insights gained from interviews with multiple patients of diverse backgrounds and from students' health-promotion and social-context (advocacy) recommendations. For educators working at institutions in the few rural areas or population centers that remain relatively untouched by migration, the experiential component might need to supplement a relatively homogeneous patient base through student participation in out-of-country immersion programs, cooperative arrangements with urban medical schools, and/or videoconferencing [187].

TC clerkships would emphasize the validation and promotion of factors that facilitate health recovery/maintenance, transnational adaptation, and survival. When working with ethnoculturally discordant patients, "the ability to identify assets in a family beset by overwhelming liabilities" as well as vulnerabilities "often produces the turning point toward successful interventions" [[188], p.269]. The bases for resilience vary among patients and are subject to change over time [189]. Possibilities for students to explore include: hopeful vision for the future; religious faith; self-reliance; personal history of overcoming adversity; roots; finding meaning/purpose in life; [189] and community mutual assistance and support [190]. In TC clerkships, students would learn that unduly pathologizing the migrant's experience [118] exaggerates deficiencies, risks fostering dependency, [191] and "removes the matter from the political and social context that produced ... [the] anguish and loss" [139]. TC clinical education also aims to provide the future physician with a toolbox of ways of reinforcing and expanding resilience (especially preparing patients to take responsibility for self care and problem solving in a confident manner, which often involves family and nonbiomedical supplements and addressing resource needs), reversing devaluation and disempowerment by providing opportunities for patients to demonstrate and develop role competence and increased control over their life both in and beyond health-care situations, [192] and enabling migrants to resist the adoption of health-adverse behaviors practiced by members of the receiving society $[193,194]$. Further- 
more, TC clerkships would demonstrate that the extra time spent on caring behavior (estimated at 5-7 minutes per encounter until the caring relationship is established) results in multiple benefits for both practitioner and patient $[137,181]$. Increasingly, managed-care providers recognize that providing such quality attention more effectively contains health-care costs than does limiting services [115].

A central component of inductive TC pedagogy and the TC clinical clerkship is a "mini ethnography" of health, illness, and migration/adaptation experiences [80,195]. In the transnational medical encounter, the patient's narrative of lived experience - including the migrant's stressful social and environmental situations, network of transnational social relations, and emerging identities [95] - is particularly valuable $[145,96]$. Genogram construction [178] constitutes another illuminating tool that can be built into the ethnographic interview. The ethnographiclearning experience should include observations in the patient's social territory; critical reflection on the medical impact of power relations, institutionalized constraints, and patient/family strengths; opportunities for the patient to comment upon the student's initial findings; preceptor feedback regarding the strengths and limitations of each student's interviews; and facilitated discussions with faculty in small-group settings of the students' findings as well as possible hidden social, economic, legal, and cultural contributors. The ethnographic approach reduces prospects that decisions will be based on stereotypic oversimplifications and/or insufficient information $[196,48,128,112]$ and helps medical practitioners avoid the overgeneralized tendency to perceive and treat migrants as traumatized victims [95].

Ethnographic interviewing also needs to be linked to skills in documenting how patient/family perspectives and insights that bear upon the patient's physical and mental health as well as his/her current social, economic, and legal circumstances will be addressed in the recommended health plan. In her case study of Lia Lee's treatment by U.S. doctors, Anne Fadiman reports that Lia's medical chart "grew longer and longer, until it contained more than 400,000 words. ... [Yet] not a single one dealt with the Lees' perception of their daughter's illness" [[81], p.259].

The TC approach involves explicit expectations that students act as the patient's advocate by forging partnerships with community organizations and advocacy groups and by making social-context recommendations that address both short- and long-term challenges to health [180,197]. Preceptors would be expected to provide feedback to students about documented results that arise from their recommendations. TC's advocacy emphasis further suggests the value of integrating community-based [156,64,36] experiential or service learning into the medical student's education [198].

Assessments of TC-learning outcomes would include student course and clerkship evaluations, student self-evaluations and instructor appraisals of pre- and postclassroom learning (e.g., the student's ability to explain why the unique migration history of a refugee from Afghanistan is important for the patient's health care [199]) and humanistic-values enhancement, review of randomly videotaped/audiorecorded encounters with patients of diverse backgrounds, [27] preceptor evaluation of each student's applications of the five TC skills (e.g., the ability to delineate and document a comprehensive plan of action that connects the patient's socio-cultural background, perspectives, and context with his/her current health challenges and promising medical and nonmedical responses), and TC-relevant OSCEs [27,184]. TC skill assessment would be incomplete without eliciting and incorporating patient reflections on the interview process, the accuracy of insights reported in the mini-ethnography, the efficacy of the student's proposed and initiated actions in terms of health-promoting interventions and personal health outcomes, [27] and the attending student's overall TC strengths and deficits.

\section{Funding}

Successful implementation of a TC educational initiative requires additional resources. The training and employment of medical interpreters, the conduct of ethnographic interviews, the professional development of medicalschool faculty who are qualified to offer TC-informed courses and to supervise TC-centered clerkships, and the construction and execution of systematic evaluation studies constitute critical components of the educational framework presented here that will be well-served by supplemental external funding. This is particularly the case for resource-scarce universities in Southern countries. In addition to internal reallocations, a variety of national and international funding sources can be mobilized for program support. Ideally, the World Health Organization would assume responsibility for driving, and coordinating funding for, the TC initiative. The faculty-development and evaluation components also would be promoted by national government incentive programs carried forward in partnership with higher-education institutions, including the United Nations University. Foundations and associations of medical professionals could usefully contribute to the global TC educational initiative, with some programs specifically devoted to the preparation of professional medical interpreters, transnational navigators, and patient advocates along with TC training for migrants. Grounding in TC, along with receptivity to continued mutual South-North learning, could be 
fruitfully incorporated into the Bill and Melinda Gates Foundation-supported "E-learning Certification Programme in Global Health" initiated through Oxford University [200] and into the post-graduate educational programs offered by the Department of Global Health at The University of Washington that will be launched in 2006 thanks to another Gates Foundation grant.

\section{Conclusion}

As the diversity of patient populations continues to expand in both North and South, it is time for a proactive and mobility-relevant redirection of medical education on a global scale. In some cases, adopting the TC framework requires fundamental shifts in orientation and approach. Other medical schools are positioned to reinforce skills already covered (e.g., ethnographic interviewing, working with intercultural mediators) within the context of TC's encompassing and globally relevant framework. The advantages of TC-inspired redirection of medical education are manifold. TC preparation (1) provides an integrated and comprehensive set of practical and contemporary medical-consultation skills of value in an age of population mobility; (2) accepts that acquired mastery of the "multiplicity of cultures that comprise the patient populations of today" [[185], p.250] is neither feasible nor necessary for quality care and cost containment; instead, the TC approach focuses on discerning each patient's multiple and complex (rather than singlesource) identities and distinctive health perspectives and personal needs in ways that build trust, confidence, and humility; (3) places the physical- and mental-health consequences of economic disparities and underlying global/ local structural contributors front and center; (4) aims to equip both service users and service providers with parallel skills [75]; (5) addresses both the quality of patient care and social constraints on migrant health; and (6) applies to and promises to resonate well with clinicians in all countries who work with ethnoculturally and socioeconomically discordant patients. Consequently, a TC education would equip learners for global and not just local practice - an important qualification given the scope of contemporary population and professional mixing.

In our mobility-upheaval era, transnational-competence preparation offers a promising avenue for providing clinicians and other public-health professionals with the full complement of interpersonal skills needed to be effective care providers in the global North and the global South. Exploratory research suggests that TC skills can improve health-care outcomes in ethnoculturally discordant medical encounters, [29,97] although confirmation requires more elaborate and comparative investigations. Given that few medical schools have embarked on pilot TC programs to date, [201] that a full-blown TC curriculum would involve demanding expectations of currently stretched students and faculty, and that compelling evaluation results require additional outcome-based research studies, controls, and time, substantiating claims for the efficacy of TC education remains a future project. However, as the value of preparation in generic TC skills is further demonstrated through student assessment, modeling by clinician mentors, mistake avoidance, [184] patient satisfaction, quality assurance, and reduced health disparities, the future physician's intrinsic human and professional motivation [202] to interact ever more effectively on behalf of ethnoculturally and socioeconomically unfamiliar and disadvantaged patients will provide the foundation for, and facilitate openness to, the development of personal transnational competence in migrant-health care.

\section{Competing interests}

The author declares that he has no competing interests.

\section{References}

I. Faist T: The volume and dynamics of international migration and transnational social spaces Oxford: Clarendon; 2000.

2. Saker L, Lee K, Cannito B, Gilmore A, Campbell-Lendrum D: Globalization and infectious diseases: A review of the linkages Geneva: World Health Organization; 2004.

3. Lee K, Dodgson R: Globalization and cholera: Implications for global governance. In health impacts of globalization: Towards global governance Edited by: Lee K. London: Palgrave Macmillan; 2003: 1 23-143.

4. Garrett L: The return of infectious disease. In Plagues and politics: Infectious disease and international policy Edited by: Price-Smith AT. London: Palgrave; 2001:183-194.

5. Cliff A, Haggett P: Disease implications of global change. In Geographies of global change: Remapping the world in the late Twentieth Century Edited by: Johnston RJ, Taylor PJ, Watts MJ. Cambridge: Blackwell; 1995:206-223.

6. Benhabib S: Borders, boundaries, and citizenship. PS: Political Science \& Politics 2005, 38(4):673-677.

7. Bernstein $\mathrm{N}$ : Record immigration is changing the face of New York's neighborhoods. New York Times :A I 6. 2005, 24 January

8. Godkin MA, Savageau JA: The effect of a global multiculturalism track on cultural competence of preclinical medical students. Family Medicine 200I, 33(3): I78-I86.

9. Pear R: Payments to help hospitals care for illegal immigrants. New York Times :AI2. 2005, I0 May

10. Lee K: $\mathbf{2 0}$ best resources on globalization. Health Policy and Planning 2004, 20(2): 137-139.

I I. Yach D, Beaglehole R: Globalization of risks for chronic diseases demands global solutions. In Globalization and health Edited by: Harris RL, Seid M. Leiden: Brill; 2004:2I 3-233.

12. Lee K, Zwi A: A global political economy approach to AIDS ideology, interests and implications. In Health impacts of globalization: Towards global governance Edited by: Lee K. London: Palgrave Macmillan; 2003:13-32.

13. Glasgow S, Pirages D: Microsecurity. In Plagues and politics: Infectious disease and international policy Edited by: Price-Smith AT. London: Palgrave; 2001:195-213.

14. Price-Smith AT: The health of nations: Infectious disease, environmental change, and their effects on national security and development Cambridge: MIT Press; 2002.

15. Brower J, Chalk P: The global threat of new and reemerging infectious diseases: Reconciling U.S. national security and public health policy Santa Monica: Rand Corporation; 2003.

16. Grondin D, Weekers J, Haour-Knipe M, Elton A, Stukey J: HealthAn essential aspect of migration management. In World migration 2003: Managing migration challenges and responses for people on the move Geneva: International Organization for Migration; 2003:85-93. 
17. Gerberding JL: SARS: Assessment, outlook, and lessons learned. Prepared witness testimony before the House Committee on Energy and Commerce, Hearing 917. 7 May 2003

18. Kickbusch IS: SARS: Wake-up call for a strong global health policy. Yale Global Online 2003 [http://yaleglobal.yale.edu/display.arti cle?id= I476]

19. Fidler DP: SARS and international law. American Society of International Law (ASIL) Insights 2003 [http://www.asil.org/insights/ insigh $101 . h \mathrm{tm}$ ]

20. Gillings A, directors, et al:: SARS: The true story (videorecording). Princeton. Films for the Humanities \& Sciences 2004.

21. McNeil DG Jr: African strain of polio virus hits Indonesia. New York Times :Al. 2005 (3 May)

22. World Health Organization: Responding to the avian influenza pandemic threat: Recommended strategic actions Geneva: WHO, Communicable Disease Surveillance and Response Global Influenza Programme, WHO/CDS/CSR/GIP/2005.8; 2005.

23. Koehn PH: Global health and human rights: Challenges for public-health administrators in an era of interdependence and mobility. In Handbook of globalization, governance, and public administration Edited by: Farazmand A, Pinkowski J. New York: Taylor \& Francis, forthcoming; 2006:104I-1069.

24. Garrett L: Fear the flu. Missoulian :B6. 2005 (12 October)

25. Yach D, Bettcher D: The globalization of public health I: Threats and opportunities. American Journal of Public Health 1998 , 88(5):735-738.

26. Whitehead $M$, Dahlgren G, Gilson L: Developing the policy response to inequities in health: $\mathbf{A}$ global perspective. In Challenging inequities in health: From ethics to action Edited by: Evans T, Whitehead M, Diderichsen F, Bhuiya A, Wirth M. Oxford: Oxford University Press; 2001:309-323.

27. Betancourt JR: Cross-cultural medical education: Conceptual approaches and frameworks for evaluation. Academic Medicine 2003, 78(6):560-569.

28. Korbin JE: Cultural issues in pediatric care. In Nelson textbook of pediatrics, I 7th edition Edited by: Behrman RE, Kliegman RM, Jensen HB. New York: Saunders; 2004: 10-12.

29. Koehn PH: Medical encounters in Finnish reception centres: Asylum-seeker and clinician perspectives. Journal of Refugee Studies 2005, I 8(I):47-75.

30. Kickbusch IS: New players for a new era: Responding to the global public health challenges. Journal of Public Health Medicine 1997, I9(2): |7|- 178

31. Kasinitz P: Race, assimilation, and 'second generations,' past and present. In Not just Black and White: Historical and contemporary perspectives on immigration, race, and ethnicity in the United States Edited by: New York: Russell Sage Foundation. Foner N, Fredrickson GM; 2004:278-298.

32. Zweifler J, Gonzalez AM: Teaching residents to care for culturally diverse populations. Academic Medicine 1998 , 73(10): 1056-106I.

33. Kagawa-Singer $M$, Kassim-Lakha S: A strategy to reduce crosscultural miscommunication and increase the likelihood of improving health outcomes. Academic Medicine 2003, 78(6):577-587.

34. Cinibulak L: The quality of reproductive health care in The Netherlands: The perspective of Turkish-Dutch women. Presentation at the International Conference on Hospitals in a Culturally Diverse Europe, Amsterdam. 2004, II December

35. Valtonen K: East meets North: The Finnish-Vietnamese community. Asian and Pacific Migration Journal 1996, 5(4):47|-489.

36. Duffy ME: A critique of cultural education in nursing. Journal of Advanced Nursing 2001, 36(4):487-495.

37. Gerrish K, Husband C, Mackensie J: Nursing for a multi-ethnic society Buckingham: Open University Press; 1996.

38. Lipson JG, Meleis Al: Research with immigrants and refugees. In Handbook of clinical nursing research Edited by: Hinshaw AS, Feetham SL, Shaver JLF. Thousand Oaks: Sage; 1999:87-106.

39. Sawyer L, et al.: Matching versus cultural competence in research: Methodological considerations. Research in Nursing and Health 1995, I8(6):557-567.

40. Al-Ali N, Black R, Koser K: The limits to 'transnationalism': Bosnian and Eritrean refugees in Europe as emerging transnational communities. Ethnic and Racial Studies 200 I, 24(4):578-600.

41. Alitolppa-Niitamo A: From the Equator to the Artic Circle: A portrait of Somali integration and diasporic consciousness in
Finland. In Rethinking refuge and displacement Edited by: Gozdziak EM, Shandy, DJ. Arlington: American Anthropological Association; 2000:43-65.

42. Kline MV, Huff RM: Moving into the 2Ist Century: Final thoughts about multicultural health promotion and disease prevention. In Promoting health in multicultural populations: A handbook for practitioners Edited by: Huff RM, Kline MV. Thousand Oaks: Sage; 1999:501-516.

43. Scott J: Life at the top in America isn't just better, it's longer. New York Times :Al8-19. 2005, 16 May

44. World Health Organization and World Bank: Dying for change: Poor people's experience of health and ill-health Washington, D.C.: World Health Organization and World Bank; 2002.

45. Lerer LB, Lopez AD, Kjellstrom T, Yach D: Health for all: Analyzing health status and determinants. World Health Statistical Quarterly 1998, 5 I (I):7-20.

46. Kickbusch IS: Hospitals as a transnational microcosm. Keynote presentation at the International Conference on Hospitals in a Culturally Diverse Europe, Amsterdam. 2004, I0 December

47. Smith C], Yang X: Examining the connection between temporary migration and the spread of STDs and HIVIAIDS in China. China Review 2005, 5(I): I I I-I39.

48. Smedley BD, Stith AY, Nelson AR, eds: Unequal treatment: Confronting racial and ethnic disparities in health care Washington, D.C.: National Academy Press; 2003

49. Kawachi I, Kennedy BP: Health and social cohesion: Why care about income inequality? British Medical Journal 1997, 3 | 4(7086): I 037- 1040.

50. Smith R: The impact of globalization on nutrition patterns: $\mathbf{A}$ case-study of the Marshall Islands. In Health impacts of globalization: Towards global governance Edited by: Lee K. London: Palgrave Macmillan; 2003:86-104.

51. Lacey M: In Africa, guns aren't the only killers. New York Times 2005, 25 Apri

52. Acevedo-Garcia D: Residential segregation and the epidemiology of infectious diseases. Social Science \& Medicine 2000 5 I: I|43-I I6I.

53. Harris RL, Seid MJ: Globalization and health in the new millennium. In Globalization and health Edited by: Harris RL, Seid MJ. Leiden: Brill; 2004: I-46.

54. Kivimaki M, Ferrie JE, Brunner E, Head J, Shipley MJ, Vahtera J, Marmot MG: Justice at work and reduced risk of coronary heart disease among employees: The Whitehall II study. Archives of Internal Medicine 2005, I 65:2245-225 I

55. Kane F, Alary M, Ndoye I, Coll AM, M'boup S, Gueye A, Kanki PJ, Joly JR: Temporary expatriation is related to HIV-I infection in rural Senegal. Current Science I993, 7(9): | 26I-I265.

56. Chen LC, Evans TG, Cash RA: Health as a global public good. In Global public goods: International cooperation in the 2 Ist Century Edited by: Kaul I, Grunberg I, Stern MA. Oxford: Oxford University Press; 1999:284-304.

57. Nadig A: Forced migration and global processes: Report of the Eighth Conference of the International Association for the Study of Forced Migration, Chiang Mai, Thailand, 5-9 January 2003. Journal of Refugee Studies 2003, I 6(4):361-375.

58. Roter DL, Hall JA: Doctors talking with patients/patients talking with doc tors: Improving communication in medical visits Westport: Auburn House; 1992.

59. Fox K: Provider-patient communication in the context of inequalities. In Child health in the multicultural environment Edited by: Silverman E. Columbus: Ross Products Division, Abbott Laboratories 2000:27-36.

60. Kaplan SH, Gandek B, Greenfield S, Rogers W, Ware JE: Patient and visit characteristics related to physicians' participatory decision-making style: Results from the medical outcomes study. Medical Care 1995, 33( I 2): I I76- I I87.

61. Alegria M, Perez DJ, Williams S: The role of public policies in reducing mental health status disparities for people of color; Public policies can improve the social conditions underlying the mental health disparities among minority populations. Health Affairs 2003.

62. Barnes DM, Harrison C, Heneghan R: Health risk and promotion behaviors in refugee populations. Journal of Health Care for the Poor and Underserved 2004, I 5(3):347-356.

63. Waitzkin $\mathrm{H}$ : The politics of medical encounters: How patients and doctors deal with social problems New Haven: Yale University Press; 1991. 
64. Wear D: Insurgent multiculturalism: Rethinking how and why we teach culture in medical education. Academic Medicine 2003, 78(6):549-554.

65. Beagan BL: Teaching social and cultural awareness to medical students: 'It's all very nice to talk about it in theory, but ultimately it makes no difference.'. Academic Medicine 2003, 78(6):605-6I4.

66. Loudon RF, Anderson PM, Gill PS, et al.: Educating medical students for work in culturally diverse societies. JAMA 1999, 282:875-880.

67. Yach D, Bettcher D: The globalization of public health II: The convergence of self-interest and altruism. American Journal of Public Health 1998, 88(5):738-74I.

68. Koehn PH, Rosenau JN: Transnational competence in an emergent epoch. International Studies Perspectives 2002, 3(May): I05-I 27.

69. Batata AS: International nurse recruitment and NHS vacancies: A cross-sectional analysis. Globalization and Health 2005, I:7.

70. Koehn NN, Fryer GE Jr, Phillips RL, Miller JB, Green LA: The increase in international medical graduates in family practice residency programs. Family Medicine 2002, 34(6):429-435

7I. Street RL Jr: Information-giving in medical consultations: The influence of patients' communicative styles and personal characteristics. Social Science and Medicine 1991, 32(5):54I-548.

72. Popay J, Williams G: Public health research and lay knowledge. Social Science and Medicine 1996, 42(5):759-768.

73. Salloway JC, Hafferty FW, Vissing YM: Professional roles and health behavior. In Handbook of health behavior research II: Provider determinants Edited by: Gochman DS. New York: Plenum Press; 1997:63-79.

74. Smith RC: The Patient's story: Integrated patient-doctor interviewing Boston: Little, Brown; 1996.

75. Koehn $\mathrm{PH}$ : Improving transnational health-care encounters and outcomes: The challenge of enhanced transnational competence for migrants and health professionals. Proceedings of the Hospitals in a Culturally Diverse Europe Conference on Qualityassured Health Care and Health Promotion for Migrants and Ethnic Minorities, Amsterdam, 9-I I December 2004 [http://www.mfh-eu.net/conf/ results/]. Posted January 2005

76. Narayan R, Schuftan C: The people's health movement: A people's campaign for 'health for all - now'. In Globalization and health Edited by: Harris RL, Seid M. Leiden: Brill; 2004:235-243.

77. Bayoumi M: Confessions of an Arab mind. Missoulian . 2004, 13 July

78. Gupta R, Yick AG: Preliminary validation of the acculturation scale on Chinese Americans. Journal of Social Work Research and Evaluation 200I, 2(I):43-56.

79. Van Wieringen JCM, Harmsen JAM, Bruijnzeels MA: Intercultural communication in general practice. European Journal of Public Health 2002, I 2(I):63-67.

80. Johnson TM, Hardt EJ, Kleinman A: Cultural factors in the medical interview. In The medical interview: Clinical care, education, and research Edited by: Lipkin M Jr, Putnam SM, Lazare A. New York: Springer; 1995: 153-162

81. Fadiman A: The spirit catches you and you fall down: A Hmong child, her American doctors, and the collision of two cultures New York: Farrar, Straus and Giroux; 1997.

82. Lustig MW, Koester J: Intercultural competence: Interpersonal communication across cultures 2nd edition. New York: HarperCollins; 1996.

83. Meleis Al, Isenberg M, Koerner JE, Lacey B, Stern P: Diversity, marginalization, and culturally competent health care issues in knowledge development Washington, D.C.: American Academy of Nursing; 1995.

84. Rynearson AM, Phillips J: Selected papers on refugee issues IV Arlington: American Anthropological Association; 1996

85. Wahlbeck O: Kurdish diasporas: A comparative study of Kurdish refugee communities New York: St. Martins; 1999.

86. Koehn PH: Refugees from revolution: U.S. policy and Third-World migration Boulder: Westview Press; 1991.

87. Kickbusch IS, Buse K: Global influences and global responses: International health at the turn of the Twenty-first Century. In International public health: Diseases, programs, systems, and policies Edited by: Merson MH, Black RE, Mills AJ. Gaithersburg: Aspen Publishers; 2001:701-732.

88. Coghlan B, Brennan RJ, Ngoy P, Dofara D, Otto B, Clements M, Stewart T: Mortality in the Democratic Republic of Congo: A nationwide survey. Lancet 2006, 367(7 January):44-5I.
89. Tavernise S: Facing chaos, Iraqi doctors are quitting. New York Times . 2005, 30 May

90. Chen LC, Berlinguer G: Health equity in a globalizing world. In Challenging inequities in health: From ethics to action Edited by: Evans T, Whitehead M, Diderichsen F, Bhuiya A, Wirth M. Oxford: Oxford University Press; 200I:35-44.

91. Porter J, Lee K, Ogden J: The globalisation of DOTS: Tuberculosis as a global emergency. In Health policy in a globalising world Edited by: Lee K, Buse K, Fustukian S. Cambridge: Cambridge University Press; 2002: I8I-194.

92. Zwi $A B$, Yach $D$ : International health in the 2 Ist Century: Trends and challenges. Social Science \& Medicine 2002 , 54(I I): $1615-1620$.

93. Bostock J, Noble $\mathrm{V}$, Winter R: Promoting community resources. In This is madness: A critical look at psychiatry and the future of mental health services Edited by: Newnes C, Holmes G, Dunn C. Ross-on Wye, U.K.: PCCS Books; 1999:24I-25I.

94. Silove D: The challenges facing mental health programs for post-conflict and refugee communities. Prehospital and Disaster Medicine 2004, I9(I):90-96.

95. Eastmond $M$ : Nationalist discourses and the construction of difference: Bosnian Muslim refugees in Sweden. Journal of Refugee Studies 1998, I I(2): |6I- |8|.

96. Kavanagh $\mathrm{KH}$ : Transcultural perspectives in mental health. In Transcultural concepts in nursing care 3rd edition. Edited by: Andrews MM, Boyle JS. Philadelphia: Lippincott; |999:223-26I.

97. Koehn PH: Transnational migration, state policy, and local clinician treatment of asylum seekers and resettled migrants: Comparative perspectives on reception-centre and community health-care practice in Finland. Global Social Policy 2006, 6(I):2I-56.

98. Allden K: The Indochinese psychiatry clinic: Trauma and refugee mental health treatment in the 1990s. Journal of Ambulatory Care Management I998, 2 I (2):30-38.

99. Anderson M, Moscou S, Fulchon C, Neuspiel DR: The role of race in the clinical presentation. Family Medicine 200I, 33(6):430-434.

100. Boyle JS: Culture, family and community. In Transcultural concepts in nursing care 3rd edition. Edited by: Andrews MM, Boyle JS. Philadelphia: Lippincott; 1999:308-337.

I0I. Meleis Al: Culturally competent scholarship: Substance and rigor. Advances in Nursing Science 1996, I 9(2): I- I6.

102. House JS, Williams DR: Understanding and reducing socioeconomic and racial/ethnic disparities in health. In Promoting health: Intervention strategies from social and behavioral research Edited by: Smedley BD, Syme SL. Washington, D.C.: National Academy Press; 2000:8I-I24

103. Liebkind K: Acculturation and stress: Vietnamese refugees in Finland. Journal of Cross-cultural Psychology 1996, 27(2): I6I-I80.

104. Lipson J, Omidian P: Health and the transnational connection: Afghan refugees in the United States. In Selected papers on refugee issues IV Edited by: Rynearson AM, Phillips J. Arlington: American Anthropological Association; 1996:2-17.

105. Ma GX: Between two worlds: The use of traditional and Western health services by Chinese immigrants. Journal of Community Health 1999, 24(6):421-437.

106. Tiilikainen M: Somali women and daily Islam in the Diaspora. Social Compass 2003, 50(I):59-69.

107. Pachter LM: Working with patients' Health Beliefs and Behaviors: The Awareness-assessment-negotiation Model in Clinical Care. In Child health in the multicultural environment Edited by: Silverman E. Columbus: Ross Products Division, Abbott Laboratories; 2000:36-43.

108. Kleinman A: Patients and healers in the context of culture: An exploration of the borderland between anthropology, medicine, and psychiatry Berkeley: University of California Press; 1980.

109. Skaer TL, Robinson LM, Sclar DA, Harding GH: Utilization of curanderos among foreign born Mexican-American women attending migrant health clinics. Journal of Cultural Diversity 1996 , 3(2):29-34.

I I0. DeSantis L: Building health communities with immigrants and refugees. Journal of Transcultural Nursing 1997, 9(I):20-3।.

III. Flores G: Culture and the patient-physician relationship: Achieving cultural competency in health care. Journal of Pediatrics 2000, I36(I): 14-23.

II2. American Medical Association: Cultural competence compendium Chicago: American Medical Association; 1999. 
113. Clapp ]: The distancing of waste: Overconsumption in a global economy. In Confronting Consumption Edited by: Princen T, Maniates M, Conca K. Cambridge: MIT Press; 2002:155-176.

1 14. Princen T, Maniates M, Conca K: Confronting consumption. In Confronting consumption Edited by: Princen T, Maniates M, Conca K. Cambridge: MIT Press; 2002:I-20.

115. Center for Mental Health Services, U.S. Department of Health and Human Services: Cultural competence standards in managed care mental health services: Four underserved/underrepresented racial/ethnic groups 2001 [http://www.mentalhealth.samhsa.gov/publications/allpubs/ SMA00-3457/default.asp].

1 16. Buchwald D, Caralis PV, Gany F, Hardt ET, Johnson TM, Mueche MA, Putsch RW: Caring for patients in a multicultural society. Patient Care 1994, 28(I I): 105-I 23.

I 17. Coulehan J], Block MR: The medical interview: Mastering skills for clinical practice 3rd edition. Philadelphia: FA Davis; 1997.

118. Green AR, Betancourt JR, Carillo JE: Integrating social factors into cross-cultural medical education. Academic Medicine 2002, 77(3): 193-197.

119. Sharma S, Code J, Riste L, Cruickshank K: Nutrient intake trends among African-Caribbeans in Britain: A migrant population and its second generation. Public Health Nutrition 1999, 2(4):469-476

120. Like R: Developing and implementing cultural competency training programs: What are we learning? Presentation at the International Conference on Hospitals in a Culturally Diverse Europe, Amsterdam. 2004, II December

121. Brock CD, Salinsky JV: Empathy: An essential skill for understanding the physician-patient relationship in clinical practice. Family Medicine 1993, 25(4):245-248.

122. Davison C, Frankel S, Smith GD: The limits of lifestyle: Re-assessing 'fatalism' in the popular culture of illness prevention. Social Science and Medicine 1992, 34(6):675-685.

123. Baron-Cohen S: The Male Condition. New York Times 2005:A19.

124. Oster N, Thomas L, Joseff D: Making informed medical decisions: Where to look and how to use what you find Beijing: O'Reilly; 2000.

125. Fishman BM, Bobo L, Kosub K, Womeodu RJ: Cultural issues in serving minority populations: Emphasis on Mexican Americans and African Americans. American Journal of the Medical Sciences 1993, 306(3): 160-166.

126. Salgado de Snyder VN, Diaz-Perez M, Maldonado M, Bautista EM: Pathways to mental health services among inhabitants of a Mexican village. Health and Social Work 1998, 23(4):249-26I.

127. Goode E: Disparities seen in mental care for minorities. New York Times :AI. 200I, 27 August

128. Nunez AE: Transforming cultural competence into cross-cultural efficacy in women's health education. Academic Medicine 2000, 75(II): $107 \mid-1080$

129. Garmezy N: Children in poverty: Resilience despite risk. Psychiatry 1993, 56(I): I27-136.

130. Stanton J, Kaplan I, Webster K: Role of Australian doctors in refugee health care. Current Therapeutics 2000, 40( (12):24-28.

131. Bandura A: Exercise of personal and collective efficacy in changing societies. In Self-efficacy in changing societies Edited by: Bandura A. Cambridge: Cambridge University Press; 1995: I-45.

132. Schwarzer R, Fuchs R: Changing risk behaviors and adopting health behaviors: The role of self-efficacy beliefs. In Self-efficacy in changing societies Edited by: Bandura A. Cambridge: Cambridge University Press; 1995:259-288.

133. Jerusalem M, Mittag W: Self-efficacy in stressful life transitions. In Self-Efficacy in Changing Societies Edited by: Bandura A. Cambridge: Cambridge University Press: 177-20I.

134. Post DM., Cegala DJ, Miser WF: The other half of the whole: Teaching patients to communicate with physicians. Family Medicine 2002, 34(5):344-352.

135. Tervalon M, Murray-Garcia J: Cultural humility versus cultural competence: A critical distinction in defining physician training outcomes in multicultural education. Journal of Health Care for the Poor and Underserved 1998, 9(2): $117-125$.

136. Salovey P, Woolery A, Mayer J: Emotional intelligence: Conceptualization and measurement. In Blackwell handbook of social psychology: Interpersonal processes Edited by: Fletcher GJO, Clark MS. Oxford: Blackwell; 200I:278-307.

137. Adler HM: The sociophysiology of caring in the doctor-patient relationship. Journal of General Internal Medicine 2002, I 7(November):874-88।.
138. Anderson JM: Immigrant women speak of chronic illness: The social construction of the devalued self. Journal of Advanced Nursing 1991, 16:710-717.

139. Gozdziak EM, Tuskan JJ: Operation Provide Refuge: The challenge of integrating behavioral science and indigenous approaches to human suffering. In Rethinking refuge and displacement Edited by: Gozdziak EM, Shandy, DJ. Arlington: American Anthropological Association; 2000:194-222.

140. Chin JL: Culturally competent health care. Public Health Reports 2000, I I 5(January/February):25-33.

141. Carrington G, Procter N: Identifying and responding to the needs of refugees: A global nursing concern. Holistic Nursing Practice 1995, 9(2):9-17.

142. Newnes C, Holmes G: The future of mental health services. In This is madness: A critical look at psychiatry and the future of mental health services Edited by: Newnes C, Holmes G, Dunn C. Ross-on-Wye: PCCS Books; 1999:273-284.

143. Flaskerud $\mathrm{JH}$ : A proposed protocol for culturally relevant nursing psychotherapy. Clinical Nurse Specialist 1987, I (4): I50-I 57.

144. Searight HR: Bosnian immigrants' perceptions of the United States health care system: Qualitative interview study. Journal of Immigrant Health 2003, 5(2):87-93.

145. Hunter KM: Doctors' stories: The narrative structure of medical knowledge Princeton: Princeton University Press; 1991.

146. Greene M: Releasing the imagination: Essays on education, the arts, and social change San Francisco: Jossey-Bass; 1995.

147. Bochner S: The social psychology of cultural mediation. In The mediating person: Bridges between cultures Edited by: Bochner S. Boston: G.K. Hall; 1981:6-36.

148. Van Selm K, Sam D, Van Oudenhoven JP: Life satisfaction and competence of Bosnian refugees in Norway. Scandinavian Journal of Psychology 1997, 38:143-I49.

149. Novack DH: Therapeutic aspects of the clinical encounter. In The medical interview: Clinical care, education, and research Edited by: Lipkin M Jr, Putnam SM, Lazare A. New York: Springer; 1995:32-49.

150. Kleinman A, Eisenberg L, Good B: Culture, illness, and care: Clinical lessons from anthropologic and cross-cultural research. Annals of Internal Medicine 1978, 88:25I-258.

15I. Wilson AH, Pittman K, Wold JL: Listening to the quiet voices of Hispanic migrant children about health. Journal of Pediatric Nursing 2000, 15(3): 137- 147.

152. Downs K, Bernstein J, Marchese T: Providing culturally competent primary care for immigrant and refugee women. Journal of Nurse-Midwifery 1997, 42(6):499-508.

153. Harwood A: Guidelines for culturally appropriate health care. In Ethnicity and medical care Edited by: Harwood A. Cambridge: Harvard University Press; 1981:482-507.

154. Martens P, Hall L: Malaria on the move: Human population movement and malaria transmission. Emerging Infectious Diseases 2000, 6(March/April): 103-II0.

155. Johnson NA, Higginbotham N, Briceno-Leon R: Best practice and future innovations in applying social science to advancing the health of populations. In Applying Health Social Science: Best Practice in the Developing World Edited by: Higginbotham N, Briceno-Leon R, Johnson NA. London: Zed Books; 2001:249-276.

156. Tervalon M: Components of culture in health for medical students' education. Academic Medicine 2003, 78(6):570-576.

157. Padgett R, Barrus AG: Registered nurses' perceptions of their communication with Spanish-speaking migrant farmworkers in North Carolina: An exploratory study. Public Health Nursing 1992, 9(3): 193-199.

158. Ferguson W], Candib LM: Culture, language, and the doctorpatient relationship. Family Medicine 2002, 34(5):353-36I.

159. Carrasquillo O, Orav EJ, Brennan TA, Burstin HR: Impact of language barriers on patient satisfaction in an emergency department. Journal of General Internal Medicine 1999, 14:82-87.

160. Baker DW, Hayes R, Fortier JP: Interpreter use and satisfaction with interpersonal aspects of care for Spanish-speaking patients. Medical Care 1998, 36: | $46 \mid-1470$.

161. David RA, Rhee M: The impact of language as a barrier to effective health care in an underserved urban Hispanic community. Mount Sinai Journal of Medicine 1998, 65(5/6):393-397.

162. Bernstein N: Language gap called health risk in E.R. New York Times :C20. 2005, 21 April

163. Struwe G: Training health and medical professionals to care for refugees: Issues and methods. In Amidst peril and pain: The 
mental health and well-being of the world's refugees Edited by: Marsella AJ, Bornemann T, Ekblad S, Orley J. Washington, D.C.: American Psychological Association; 1994:31 I-324.

164. Hardt E): The bilingual interview and medical interpretation. In The medical interview: Clinical care, education, and research Edited by: Lipkin MJr, Putnam SM, Lazare A. New York: Springer; 1995: 172 - 177.

165. Elderkin-Thompson V, Silver RC, Waitzkin H: When nurses double as interpreters: A study of Spanish-speaking patients in a US primary care setting. Social Science and Medicine 200I, 52:1343-| 358.

166. Kuo D, Fagan MJ: Satisfaction with methods of Spanish interpretation in an ambulatory care clinic. Journal of General Internal Medicine 1999, 14:547-550.

167. Waitzkin H: Doctor-patient communication: Clinical implications of social scientific research. JAMA 1984, 252(I7):244I-2446.

168. DiMatteo MR: Health behaviors and care decisions. In Handbook of health behavior research II: Provider determinants Edited by: Gochman DS. New York: Plenum Press; 1997:5-22.

169. Wooldridge B: Foreigner talk': An important element in crosscultural management education and training. International Review of Administrative Sciences 200I, 67(4):62I-634.

170. Lausch C. Heuer L, Guasasco C, Bengiamin M: The experiences of migrant health nurses employed in seasonal satellite nursemanaged centers: A qualitative study. Journal of Community Health Nursing 2003, 20(2):67-80.

17I. Greenfield S, Kaplan S, Ware JE: Expanding patient involvement in care. Annals of Internal Medicine 1985, 102:520-528.

172. Brach C, Fraser I: Can cultural competency reduce racial and ethnic health disparities? A review and conceptual model. Medical Care Research and Review 2000, 57(Supplement I): | 8I-2I7.

173. Miller KE: Rethinking a familiar model: Psychotherapy and the mental health of refugees. Journal of Contemporary Psychotherapy 1999, 29(4):283-306.

174. Farmer P: Infections and inequalities: The modern plagues Berkeley: University of California Press; 1999.

175. Pappas G: Some implications for the study of the doctorpatient interaction: Power, structure, and agency in the works of Howard Waitzkin and Arthur Kleinman. Social Science and Medicine 1990, 30(2): 199-204.

176. Smedley BD, Syme SL: Promoting health: Intervention strategies from social and behavioral research. In Promoting health: Intervention strategies from social and behavioral research Edited by: Smedley BD, Syme SL. Washington, D.C.: National Academy Press; 2000:I-36.

177. Lee K, Fustukian S, Buse K: An introduction to global health policy. In Health policy in a globalising world Edited by: Lee K, Buse K, Fustukian S. Cambridge: Cambridge University Press; 2002:3-17.

178. Cook A, England R: Pain in the heart: Primary care consultations with frequently attending refugees. Primary Care Mental Health 2004, 2(June): 107-III.

179. Watters $C$ : Emerging paradigms in the mental health care of refugees. Social Science and Medicine 200I, 52:1709-1718.

180. Verwey S, Crystal A: Provider-patient communication in the African health context. In Health communication in Africa: Contexts, constraints and lessons Edited by: Alali AO, Jinadu BA. Lanham: University Press of America; 2002:8I- 108.

18I. Stewart AL, Napoles-Springer A, Perez-Stable EJ, Posner SF, Bindman $A B$, Pinderhughes $H L$, Washington $A E$ : Interpersonal processes of care in diverse populations. Milbank Quarterly 1999, 77(3):305-339.

182. Cassell EJ: The healer's art Cambridge:MIT Press; 1976.

183. Swick HM: Toward a normative definition of medical professionalism. Academic Medicine 2000, 75:612-6I6

184. Kai J, Bridgewater R, Spencer J: '"Just think of TB and Asians', that's all I ever hear": Medical learners' views about training to work in an ethnically diverse society. Medical Education 200I, 35:250-256.

185. Shapiro J, Lenahan P: Family medicine in a culturally diverse world: A solution-oriented approach to common cross-cultural problems in medical encounters. Family Medicine 1996, 28(4):249-255.

186. Goldman RE, Monroe AD, Dube CE: Cultural self-awareness: A component of culturally responsive patient care. Annals of Behavioral Science and Medical Education 1996, 3(I):37-46.
187. Ekblad S, Manicavasagar V, Silove D, Baarnhielm S, Reczycki M, Mollica $R$, Coello $M$ : The use of international videoconferencing as a strategy for teaching medical students about transcultural psychiatry. Transcultural Psychiatry 2004, 4I(I): I20-I29.

188. McPhatter AR: Cultural competence in child welfare: What is it? How do we achieve it? What happens without it? Child Welfare 1997, 76(I):255-278.

189. Lothe EA, Heggen K: A study of resilience in young Ethiopian famine survivors. Journal of Transcultural Nursing 2003, 14(4):3। 3-320.

190. Valtonen K: The adaptation of Vietnamese refugees in Finland. Journal of Refugee Studies 1994, 7(1):63-78.

191. Ager A: Perspectives on the refugee experience. In Refugees: Perspectives on the experience of forced migration Edited by: Ager A. London: Pinter; 1999:I-23.

192. Cowen EL: In pursuit of wellness. American Psychologist 1991, 46(4):404-408.

193. Barnes DM, Harrison C, Heneghan R: Health Risk and Promotion Behaviors in refugee Populations. Journal of Health Care for the Poor and Underserved 2004, 15(3):347-356.

194. Tanner L: Obesity big problem for immigrants. Missoulian . 2004, 15 December

195. Lecca PJ, Quervalu I, Nunes JV, Gonzales HF: Cultural competency in health, social, and human services New York: Garland; 1998.

196. Andrews MM: Theoretical foundations of transcultural nursing. In Transcultural concepts in nursing care 3rd edition. Edited by: Andrews MM, Boyle JS. Philadelphia: Lippincott; 1999:3-22.

197. The Amsterdam Declaration: Towards migrant friendly hospitals in an ethno-culturally diverse Europe [http://www.mfheu.net]

198. Barrier P: Report on the Mayo Medical Center's year-one TC service-learning elective. presented at the GEA/GSA Mini-Workshop Session on "Moving Beyond Cultural Competence: Transnational Competence in Undergraduate Medical Education," 2005 Annual Meeting ("Beyond Boundaries") of the Association of American Medical Colleges, Washington, D.C. 8 November 2005

199. Papadopoulos I, Tilki M, Taylor G: Developing transcultural skills. In Transcultural care: $A$ guide for health care professionals Edited by: Papadopoulos I, Tilki M, Taylor G. Trowbridge, UK: Redwood Books; 1998:|75-2|1.

200. Cutting-edge health care training in Africa [http:// www.tall.ox.ac.uk/tallinternet/projects.asp]. Accessed I4 April 2003

20I. Koehn PH, Swick HM: Preparing transnationally competent physicians for migrant-friendly health care: New directions in U.S. medical education. Proceedings of the hospitals in a culturally diverse Europe conference on quality-assured health care and health promotion for migrants and ethnic minorities, Amsterdam [http://www.mfheu.net/conf/results/]. 9-II December 2004

202. De Young R: Expanding and evaluating motives for environmentally responsible behavior. Journal of Social Issues 2000, 56(3):509-526.

Publish with Bio Med Central and every scientist can read your work free of charge

"BioMed Central will be the most significant development for disseminating the results of biomedical research in our lifetime. "

Sir Paul Nurse, Cancer Research UK

Your research papers will be:

- available free of charge to the entire biomedical community

- peer reviewed and published immediately upon acceptance

- cited in PubMed and archived on PubMed Central

- yours - you keep the copyright
BioMedcentral 